\title{
Seismic Monitoring of Poland - Description and Results of Temporary Seismic Project with Mobile Seismic Network
}

\author{
Jacek TROJANOWSKI, Beata PLESIEWICZ, \\ and Jan WISZNIOWSKI \\ Institute of Geophysics, Polish Academy of Sciences, Warszawa, Poland \\ e-mail: jtroj@igf.edu.pl
}

\begin{abstract}
The paper describes a temporary seismic project aimed at developing the national database of natural seismic activity for seismic hazard assessment, officially called "Monitoring of Seismic Hazard of Territory of Poland" (MSHTP). Due to low seismicity of Poland, the project was focused on events of magnitude range 1-3 in selected regions in order to maximize the chance of recording any natural event. The project used mobile seismic stations and was divided into two stages.

Five-year measurements brought over one hundred natural seismic events of magnitudes $M_{L}$ range $0.5-3.8$. Most of them were located in the Podhale region in the Carpathians. Together with previously recorded events this made it possible to conduct a preliminary study on ground motion prediction equation for this region. Only one natural event, of magnitude $M_{L}=3.8$, was recorded outside the Carpathians in a surprising location in central-west Poland.
\end{abstract}

Key words: seismic monitoring, mobile network, seismicity of Poland, GMPE. 


\section{INTRODUCTION}

Although Poland is known as a region of very low natural seismicity, some earthquakes occur there from time to time. The historical catalogue (Guterch B. 2009) consists of less than one hundred earthquakes in the time span of almost one thousand years (Fig. 1).

There are two main regions of natural seismicity - mountains in south Poland and Teisseyre-Tornquist Zone (TTZ), which passes through Poland as about $100 \mathrm{~km}$ wide band from NW to SE.

The TTZ is a passive contact zone between two stable platforms - the Precambrian East European Craton (EEC) and the Paleozoic West European Platform (WEP). This complicated and very interesting structure is very difficult to study because it is covered by thick sediments. Most of our knowledge about it comes from three wide-angle experiments covering Poland and vicinity with many 2D profiles: POLONAISE'97 (Guterch A. et al.

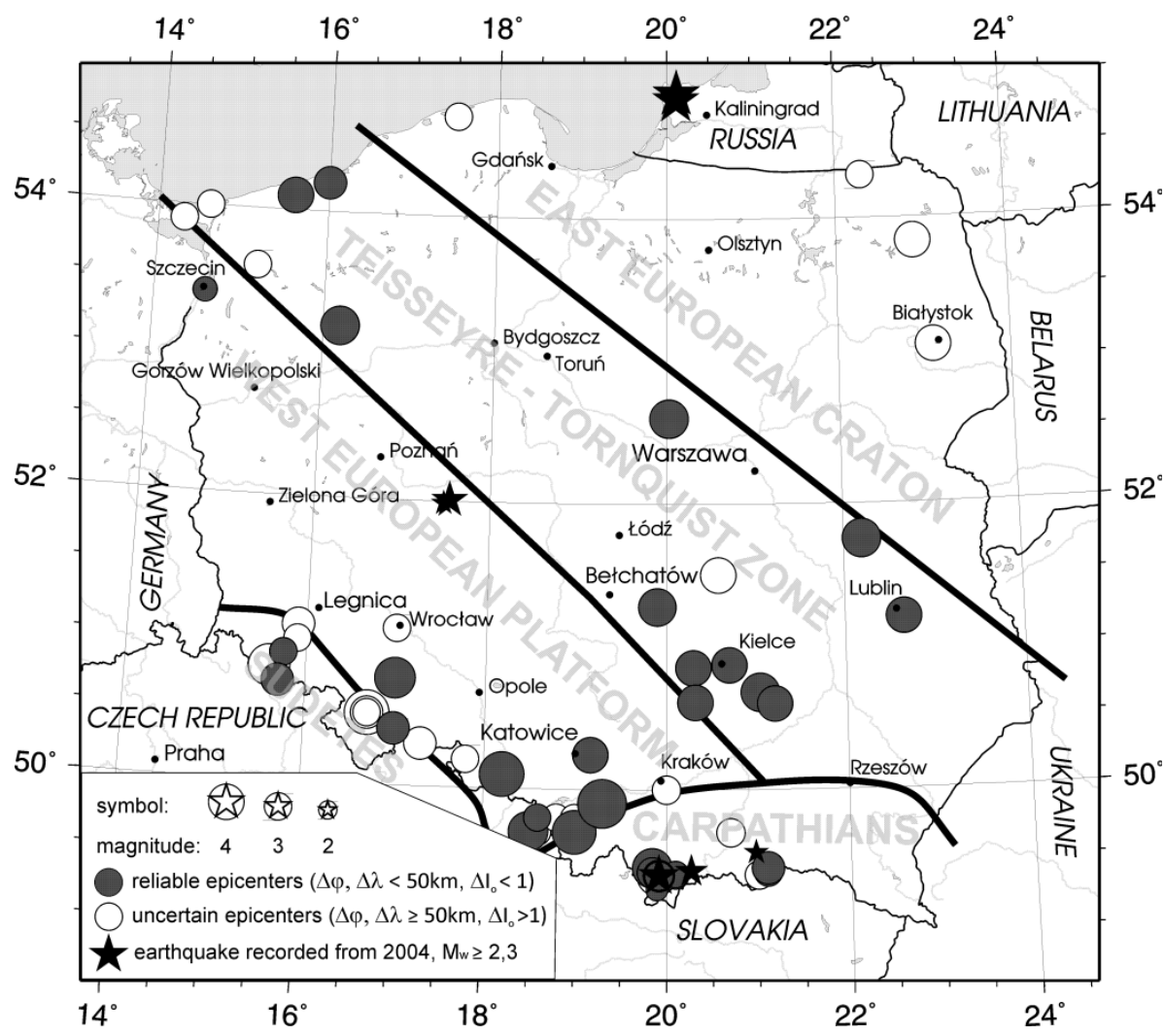

Fig. 1. Maps of the historical seismicity and strong recent earthquakes from 1400 to 2012 (data after Guterch B. (2009) and MSHTP). 
1999), CELEBRATION 2000 (Guterch A. et al. 2003), and SUDETES 2003 (Grad et al. 2003).

A stable area of central and north Poland is pushed from the south by the Carpathians, which is manifested in mountains in south and south-east Poland. The Carpathians is young active orogen, contrary to older, Variscan Sudetes in south-west Poland.

Regardless of these significant genetic differences, south Poland in general is a site of the majority of earthquakes including the biggest ones, with maximum intensity of 7 in EMS-98 scale. The reason for using the EMS intensity scale, instead of magnitude, is that the biggest earthquakes occurred before any form of seismic measurement was set up in the area.

In other parts of Poland, there were much fewer earthquakes and they were smaller, hardly ever reaching intensity 6 . But there is a spectacular exception of a recent well described earthquake -5.2 magnitude earthquake on 21 September 2004 in Kaliningrad Oblast, about $50 \mathrm{~km}$ from the PolishRussian border (Wiejacz 2006, Domański 2007). It was felt in the whole north Poland causing minor losses. It was also felt in Sweden and even Denmark. Together with another earthquake in southern Poland the same year, it was probably one of the important reasons for establishing the project focused on natural seismicity.

The project assumptions were based on historical seismicity (Guterch 2009) and seismic hazard study for Polish area (Schenk et al. 2000). Parameters of seismic hazard made it possible to assess that earthquake occurrence rate in the regions being considered is high enough to record at least a few events of magnitudes above $M_{L}=1$. Because of too large area to monitor with 24 stations assigned to the project, it was decided to monitor only selected areas with the highest occurrence rate of earthquakes. Additionally, the project was divided into two 2.5 -year stages. Some practical experience was gained during realization of PASSEQ experiment in the years 20062008 (Wilde-Piórko et al. 2008) which comprised almost 200 stations in temporary locations. On the contrary, though, in MSHTP the stress was put on mobility and immediate data transfer. In case of an exceptionally large event (above $M_{L}=3$ ) it was assumed that some of the stations have to be able to be moved in two days from current positions to the epicentral area.

Although the project was focused on the natural seismicity only, there are regions of Poland with relatively high induced seismicity. The strongest earthquakes are induced by copper mines near Legnica and Głogów in southwest Poland and can exceed magnitude $M_{L}=4$, which happens almost every year (e.g., Lizurek and Wiejacz 2011, Orlecka-Sikora et al. 2012, Idziak and Dubiel 2011). Other regions highly influenced by induced seismicity is Upper Silesia in south Poland, where big coalfields have been intensively exploited for last centuries (Zuberek and Jochymczyk 2010) and Bełchatów 
brown coal open-cast mine region (Wiejacz and Rudziński 2010). Events in these regions were not analyzed. There exist local networks maintained by mines and controlled by appropriate authorities, which monitor regions of induced seismicity.

\section{INSTRUMENTATION}

Mobile seismic network requires transportable equipment which can be easily deployed without much effort to prepare the site. The Institute of Geophysics, Polish Academy of Sciences (IGF PAS) decided to use its long experience in the field of developing data loggers (e.g., Aleksandrowicz 1982, Hościłowicz et al. 1990, Olszewski and Wiszniowski 1993) and launched a new Net Data Logger (NDL) in 2008. The NDL served in the project with a sampling rate of 100 sps and dynamics of $132 \mathrm{~dB}$. Continuously recorded data were stored on Compact Flash in the internal data format and immediately transferred through the Internet provided by GSM operators. The NDL together with external devices form a mobile station.

All stations were equipped with three-component short-period seismometers Lennartz LE-3DLite $(1 \mathrm{~Hz})$, which are appropriate to measure local and regional seismicity, as the main content of seismic waves comes in the range of a few Hz. Additionally, this type of seismometers is easy to handle and does not require time-consuming procedure as most long period seismometers (e.g., STS-2), which is very important for projects requiring high mobility of stations.

Data downloaded from the stations are collected and archived by the SeisComp system (www.seiscomp3.org/wiki/doc). During the whole project, SeisComp has been extended and supplemented by our components which support handling a seismic network. It comprises a set of tools to control network status and check data quality.

For data processing there was chosen a Seismic Wave Interpretation Program (SWIP) developed by IGF PAS for the purpose of routine job in seismological observatories (private.igf.edu/ jwisz). It has a direct connection to MySQL data base of events and to all recorded data (via ArcLink protocol).

\section{DETECTION METHODS}

At first, only visual inspection of seismograms was done but it shortly appeared to be time consuming and not reliable. As the acquisition was based on SeisComp system, tools built in this system were tested - AutoPick and AutoLoc. Unfortunately, they are meant for other recording conditions. AutoPick is based on the ratio of Short Term Average to Long Term Average (STA/LTA), which makes it vulnerable to high amplitude disturbances 
and generates many false detections which makes these tools inapplicable for our data.

The problem was that most stations were deployed in temporary locations close to human neighborhoods, which causes a high level of noise and disturbances in recorded seismic signal. Therefore, detection of small events is associated with unacceptable number of false detections.

It was decided to apply Real Time Recurrent Neural Network (RTRN) to detect small natural seismic events. It had already been studied on regional events by Wiszniowski (2000) but it got accommodated for local events (Wiszniowski et al. 2014). This method is able to assess relations of seismic signal in frequency domains as well as in time of seismic phases.

\section{MEASUREMENTS}

The seismic network used in MSHTP is registered in IRIS with a name PD Polish Seismic Monitoring Network, but as a mobile network; individual station names have not been reserved. The full list of all stations which worked in the project is listed in the Appendix 1 and shown on maps in Figs. 2 and 3 for the first and the second stage of the project, respectively.

According to the contract with the project founder, in case of appearance of a natural earthquake of significant scale, some stations should be moved to the epicenter area in 48 hours to monitor potential aftershocks. For this reason, stations are designed and deployed so as to make mobilization and demobilization easy, without expensive and time-consuming site preparation.

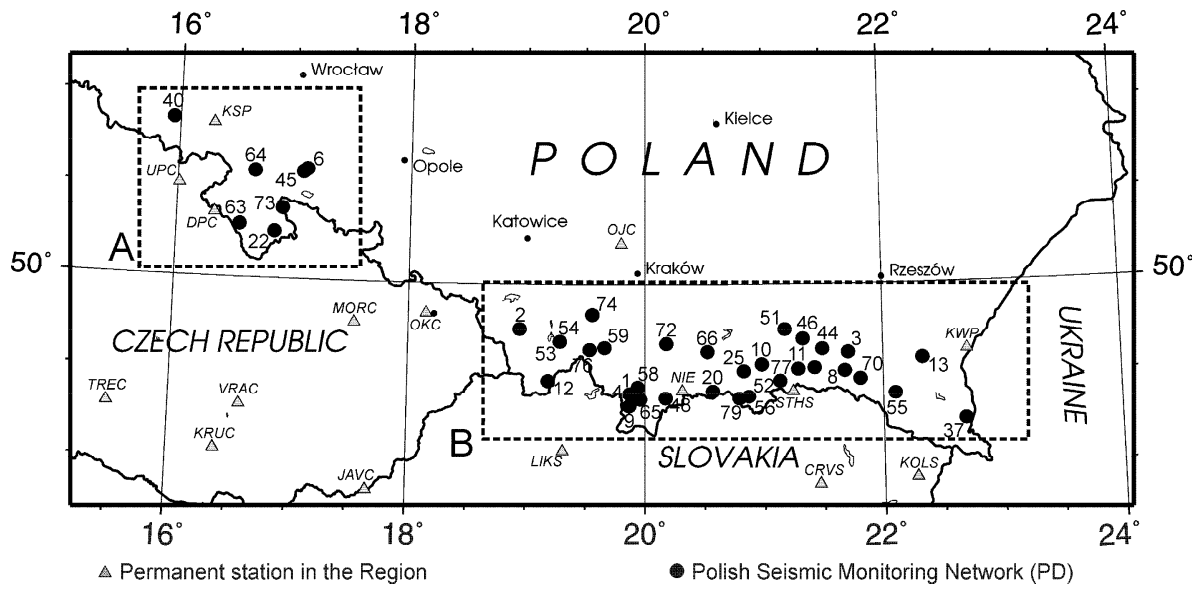

Fig. 2. Locations of stations in the Sudetes (region A) and Carpathians (region B) during the first stage of MSHTP in 2008-2010 (circles). Other stations in the region are marked by triangles. 


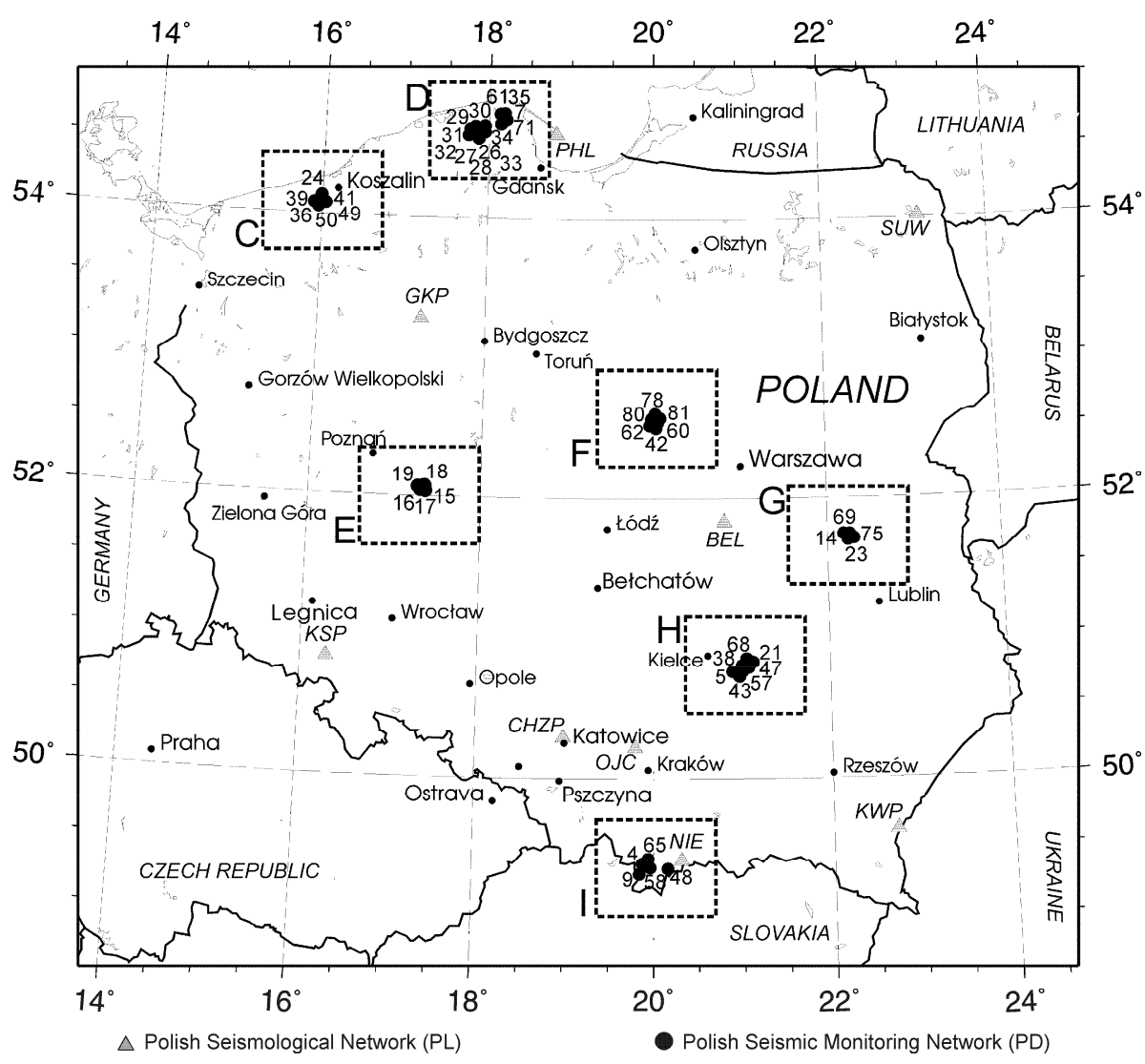

Fig. 3. All seismic stations maintained by IGF PAS during the second stage of MSHTP in the years 2010-2012 (circles). Other stations in the region are marked by triangles. Monitored regions: C - West Pomerania / near Koszalin, D - Pomerania / vicinity of Łebień and Żarnowiec, E - Wielkopolska / near Jarocin, F - Mazovia / near Płock, G - Mazovia / near Łuków, H - Holly Cross Mountains, I - Podhale / Tatra Mountains.

The project was focused on areas of known historical seismic activity. In the first stage, the monitoring covered mountain regions of the Sudetes and Carpathians in south Poland, where the majority of historical earthquakes occurred (Fig. 2). In the second stage, several regions of central and north Poland were selected (Fig. 3). It was assumed that in these places it is most probable to find seismic activity, although among these regions the region of Holy Cross Mountains has exceptionally high seismic hazard parameters (Schenk et al. 2000) which suggested very high chance of recording natural events. Additionally, three stations have remained during second stage in 
Podhale/Carpathians, where continuous seismicity was discovered in the first stage.

Locations were selected in order to have good coverage of the monitored area and to avoid noisy areas. The second requirement means in general that stations should be put far from highly populated areas but it entails problems with infrastructure which is necessary to provide a station with power supply and internet access. Especially in mountains there was often a lack of GSM signal, which was necessary to transmit data. In most cases, stations were installed in private properties to assure protection and power supply. Although station locations were carefully selected, no tests were performed prior to station deployment. As a result, it was often necessary to move stations because of disturbances or high noise level which appeared after a station had been deployed. However, this was relatively easy due to simple installation procedure. Such a trial-error method led to 38 station locations during the first stage and 46 during the second stage.

\section{Signal quality in different regions of Poland}

Recording conditions in Poland vary because of differences in population density, industrialization, and geology. In general, low noise level is in southern Poland - in mountains. In central and northern Poland there are thick sediment layers and soils without any outcrops which are associated with higher noise level. Site selection and verification was carried out for every potential seismic station. A very useful criterion for noise assessment was to analyze power spectrum density of the recorded ground velocity. Sometimes high amplitude noise is concentrated around particular frequencies or frequency bands, which makes it possible to filter it out. This is especially easy for most signals generated by machines. The worst possible kind of noise is that related to the whole band of seismic waves (a few $\mathrm{Hz}$ ), which makes it impossible to filter it out without significant loss of the seismic signal. Useful information about human generated noise comes from a comparison of day and night spectra, as human activity is usually higher during a day.

A comparison of power spectrum density for different regions of Poland is presented in Fig. 4. Day and night spectra were calculated for all stations and then averaged to represent respective regions. All spectra are plotted in the same scale to make it possible to easily compare noise levels between regions.

The best signal is in mountain regions, for which velocity power spectra density stays below $10^{-16}(\mathrm{~m} / \mathrm{s})^{2} / \mathrm{Hz}$ (regions A and B) or $10^{-15}(\mathrm{~m} / \mathrm{s})^{2} / \mathrm{Hz}$ (region $\mathrm{H}$ ). All other regions with sedimentary background have values varying between $10^{-15}(\mathrm{~m} / \mathrm{s})^{2} / \mathrm{Hz}$ and $10^{-13}(\mathrm{~m} / \mathrm{s})^{2} / \mathrm{Hz}$. 

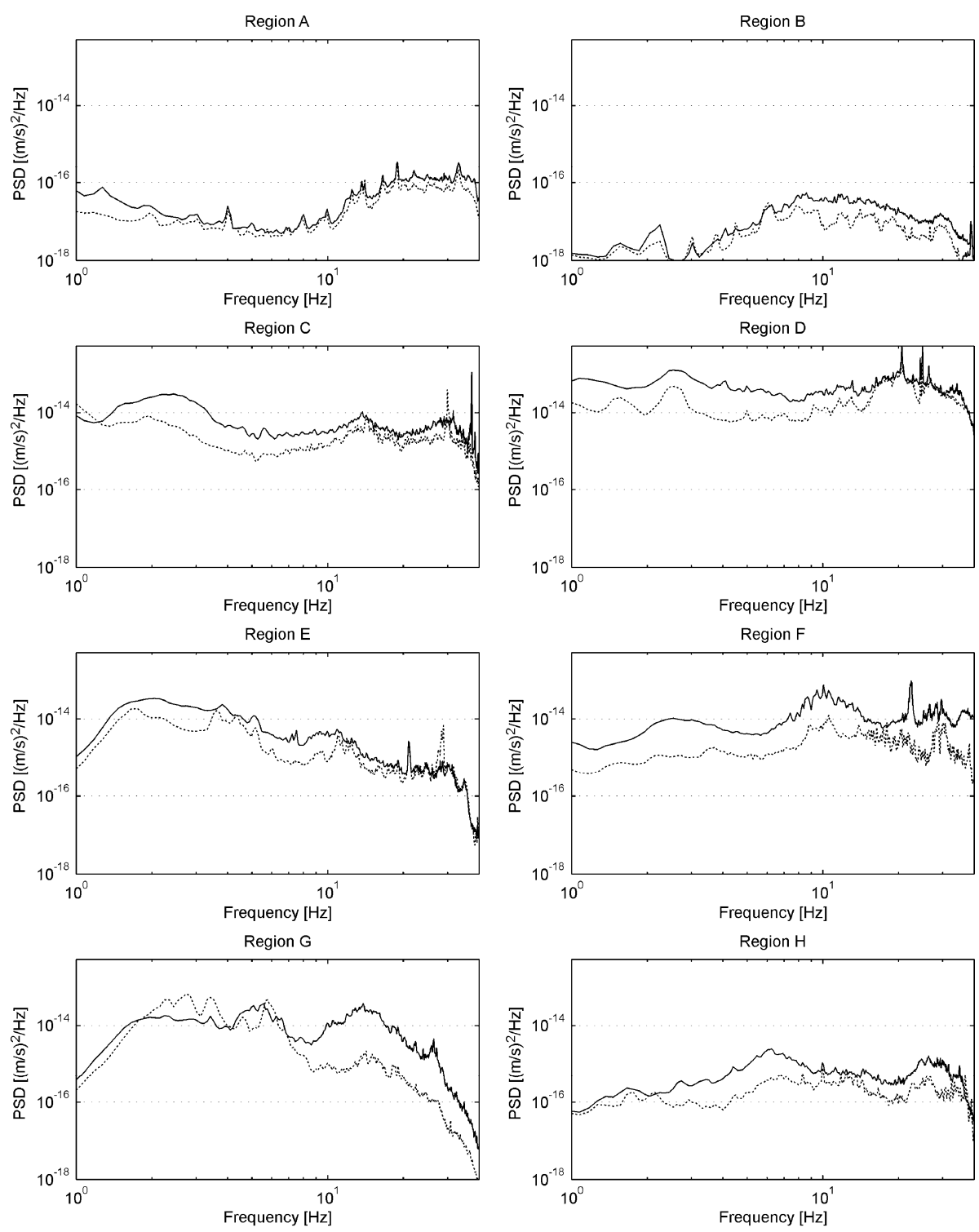

Fig. 4. Velocity power spectra density for stations in regions A-H shown in Figs. 2 and 3. Day spectra - solid line, night spectra - dashed line. Few days with small wind speed (average day wind speed below $3 \mathrm{~m} / \mathrm{s}$ ) were selected in each region. Day was defined as a time between 6 a.m. and 6 p.m. local time. 


\section{RESULTS}

\section{General description}

The first stage of MSHTP covered southern Poland where the probability of earthquake occurrence is the highest. Indeed, it has been confirmed that Podhale is seismically active (over 100 events). There were also two microearthquakes recorded near Krynica in Beskid Sądecki. In other places monitored during the first stage of MSHTP, no natural event was recorded.

Places of previously recognized seismic activity in TTZ became the object of seismic monitoring in the second stage of MSHTP. Most of the stations were put in regions with thick sediment and soil layers which makes the noise level high. From this point of view, stations in Holy Cross Mountains had good recording conditions but a problem was with high activity of quarries in the region. To distinguish its records from natural events, source location and spectrograms of the recorded signal were analyzed. Finally, during the entire MSHTP no natural seismic event was found in the whole TTZ.

The last not described region of Poland is Wielkopolska in centralwestern Poland. It is a part of WEP and by January 2012 there was no single earthquake known there. Surprisingly, on 6 January 2012 at 15:38 UTC an earthquake of magnitude $M_{L}=3.8$ frightened inhabitants of the area in a radius of $10 \mathrm{~km}$ from the epicenter. Later, macroseismic questionnaires were coming from distances over $60 \mathrm{~km}$ from the epicenter. Unfortunately, this region was not monitored and the nearest stations were about $100 \mathrm{~km}$ off. Immediately after the earthquake, five stations were moved there from other regions. The earthquake was described in detail by Lizurek et al. (2013).

Apart from seismic events, both natural and man-induced, there were also recorded non seismic events considered generally as disturbances but they are rarely recorded by more than one station. If so, it is necessary to verify a possible source to distinguish it from possibly natural seismic source. Events of this kind may be, for example, quarry blasts or jet sonic waves.

The next two sections describe in more details natural seismicity recorded in the project and an interesting example of non-seismic events recorded on an exceptionally large area. The last section concerns derivation of ground motion prediction equation (GMPE) for the Podhale region / Carpathians.

\section{Seismicity of the Carpathians (Polish part)}

Earthquakes felt in the Polish Carpathians were known for many years. Some of them are only mentioned in chronicles but more recent ones are better described (Guterch B. et al. 2005, Guterch B. 2006, 2007, 2009, Wiejacz and Dębski 2009). Seismicity concentrates in the west part of the region - in 
the Podhale but some events occur also in the east part, mainly in Beskid Saqdecki (Fig. 5). Before 2008, seismic events were rarely recorded but the MSHTP project has shown a continuous activity. Figure 6 shows an increasing capability to detect seismic events in this region with the majority of events recorded during the MSHTP project. In the Podhale region, where

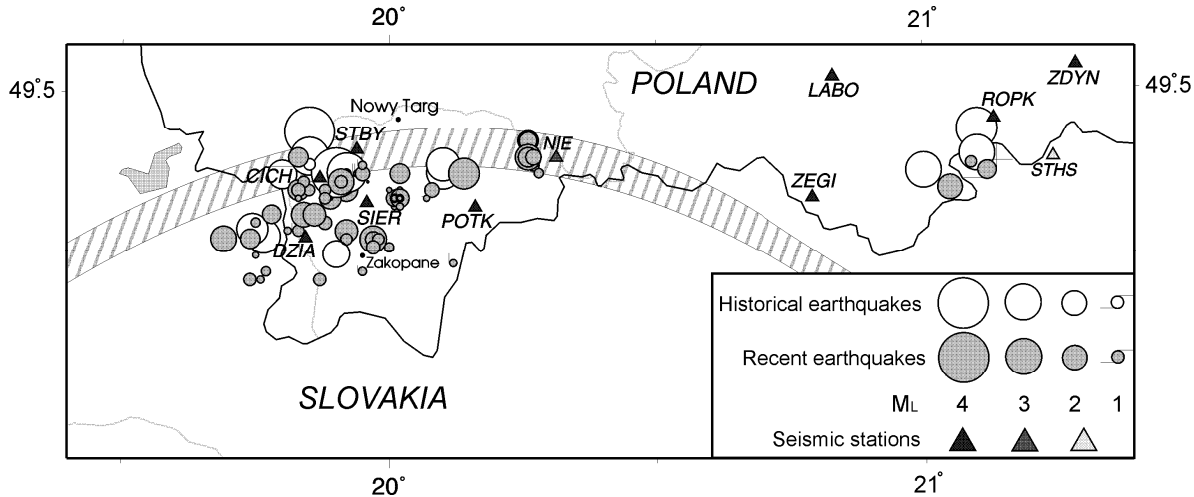

Fig. 5. Seismic events in Podhale. The most important geological structure is PKB Pieniny Klippen Belt (hatched area). Seismic stations are marked with triangles.
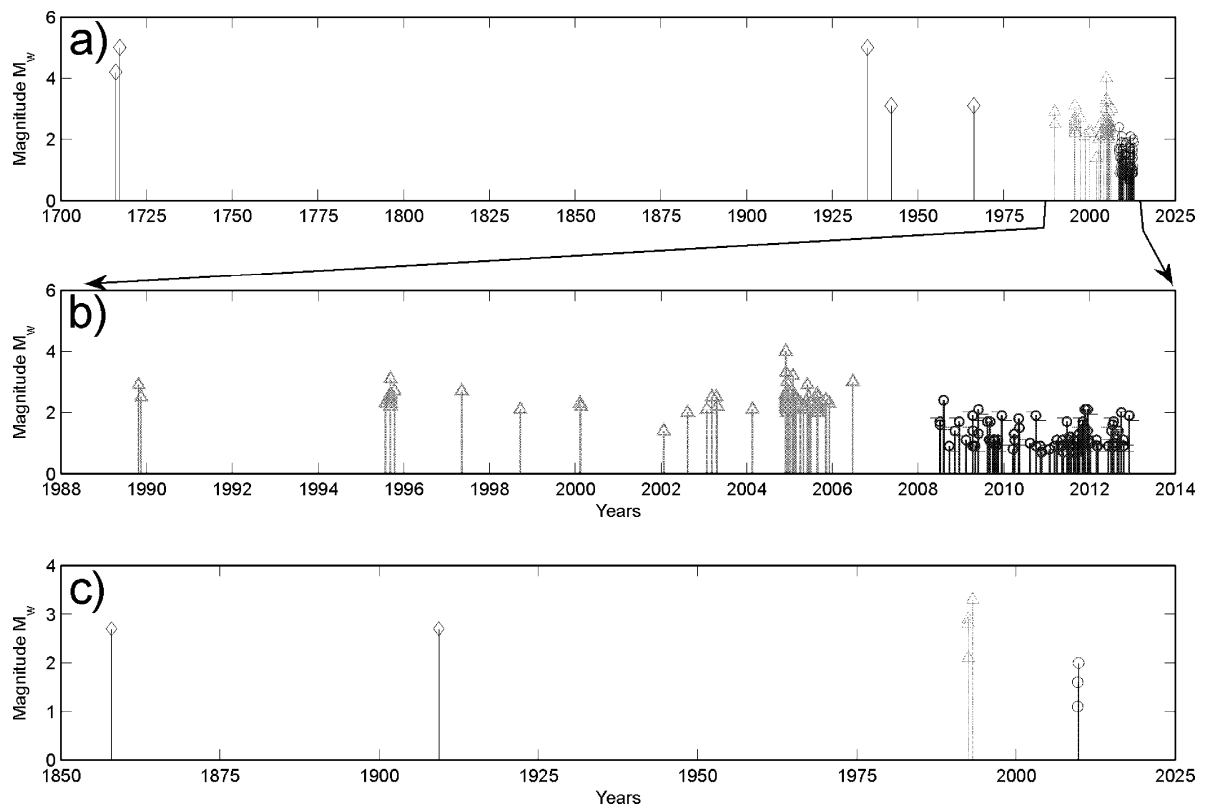

Fig. 6. Time sequence of all earthquakes in the Polish Carpathians separated into the Podhale region - panels (a) and (b), and Beskid Sądecki - panel (c). Diamonds historical earthquakes, triangles - recorded instrumentally, and circles - recorded during MSHTP. 


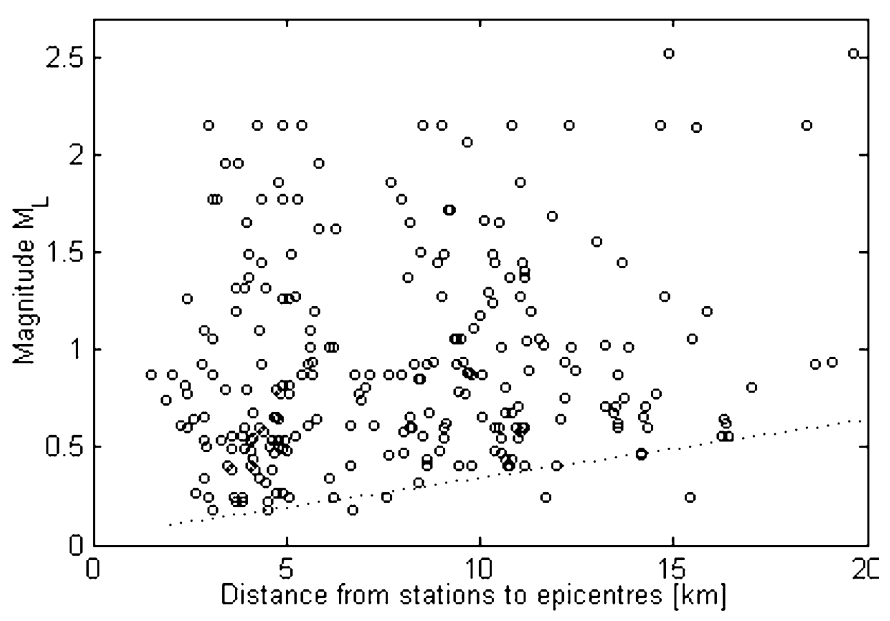

Fig. 7. The dashed line on the diagram shows a sensitivity of the network in the Podhale region. Each circle represents a magnitude calculated for an individual station.

several seismic events were recorded, a sensitivity of the seismic network, in terms of a minimum magnitude possible to be detected at a given distance, is shown on a diagram in Fig. 7. Generally, events below a dashed cut-off line are not detectable by this network, although in very good recording conditions it happens.

Over one hundred microearthquakes have been detected and 81 of them, of magnitude $\left(M_{L}\right)$ range from 0.5 to 2.2, located (Appendix 2). Some of them are part of a swarm which took place in November-December 2011. All of the swarm events are located in the Pieniny Klippen Belt (PKB) formation and may be related to a nearby Czorsztyńskie Lake - an artificial reservoir on the Dunajec River, whereas the majority of other events are located to the south of PKB and are not related to the lake. In general, active regions fit well with regions where stronger events were recorded previously (Fig. 5).

Although the number of records was not sufficient to conduct full moment tensor analysis, it was possible to derive basic spectral parameters. The values of $\Omega_{0}$ and $f_{0}$ of Brune's (1970) model were calculated separately for three components using the method of Andrews (1986). The spectrum of the signal was computed by the multitaper method of Park et al. (1987) with scaling of the spectra based on the Parseval equality. The seismic moment was calculated from three components (Wiejacz and Wiszniowski 2006).

There were selected three events of magnitude $M_{L}=1$ and three of $M_{L}=2$. A corner frequency $\left(f_{0}\right)$ calculated for different stations was for $M_{L} \sim 1$, in the range of $5.9-11.9 \mathrm{~Hz}$ for $P$ waves and $3.6-7.2 \mathrm{~Hz}$ for $S$ waves. For 
stronger events, of magnitude $M_{L} \sim 2$, the calculated $f_{0}$ was in the range of 4.1-11.7 Hz for $P$ waves and 3.3-7.3 Hz for $S$ waves. Spectral parameters for events of $M_{L}=1$ are less reliable because, as a result of inelastic dumping, high frequency signal is below the noise level.

\section{Ground Motion Prediction Equation (GMPE) for Podhale}

Relatively high number of seismic events recorded in Podhale / West Polish Carpathians allowed us to derive GMPE for this region. The only equation used before was a very general equation used by Shenk et al. (2000) to jointly describe Czech, Polish, and Slovak region.

At first, a standard regression model of GMPE was used, which assumes geometric damping

$$
\log Y=a_{1}+a_{2} m+a_{3} \log \sqrt{d^{2}+h^{2}},
$$

where $Y$ is the Peak Horizontal Acceleration (PHA) $\left[\mathrm{m} / \mathrm{s}^{2}\right], m$ the magnitude, and $d$ the distance [km]. Coefficients $a_{1}, a_{2}, a_{3}$, and $h$ were estimated using three methods (Joyner and Boore 1993): single stage regression (SSR), two stage regression (TSR), and least squares. The results are presented in Table 1.

Table 1

Coefficients of Eq. 1 computed using different regression methods

\begin{tabular}{|c|c|c|c|c|c|}
\hline Regression method & $a_{1}$ & $a_{2}$ & $a_{3}$ & $h$ & $\sigma$ \\
\hline SSR & -1.6957 & 1.1251 & -2.7167 & 7.0646 & $0.255(\gamma=0.009)$ \\
TSR & -2.1658 & 1.1105 & -2.4095 & 4.8663 & $0.25\left(\sigma_{e}=0.096\right)$ \\
Least squares & -2.0945 & 1.0985 & -2.4438 & 5.2665 & 0.25 \\
\hline
\end{tabular}

All three methods gave similar results within $30 \%$ confidence interval. Then, stability of the solution was tested for different distances to the epicenter (Table 2). Small variation of the parameters at every distance indicates good fit to the data, which can also be visually inspected in Fig. 8.

Apart from the standard form of the GMPE of Eq. 1, a GMPE with assumed anelastic damping was also tested. It is given by the general equation

$$
\log Y=a_{1}+a_{2} m-\log \sqrt{d^{2}+h^{2}}+a_{3} d
$$

and gave very similar results, in terms of $\sigma$ value, to previous GMPE model for all source-receiver distances, although data extended by older events does not fit as well as previously, having higher $\sigma$-value (Table 3 ). This means that the previous GMPE model with elastic damping is better for the region of Podhale. 
Coefficients of the GMPE equation

calculated for events within different distances to the epicenter

\begin{tabular}{|c|c|r|r|r|r|r|}
\hline Distance limit & Data points & \multicolumn{1}{c|}{$a_{1}$} & \multicolumn{1}{c|}{$a_{2}$} & $a_{3}$ & \multicolumn{1}{c|}{$h$} & \multicolumn{1}{c|}{$\sigma$} \\
\hline 5 & 88 & -2.4716 & 1.1782 & -2.2901 & 5.2500 & 0.2055 \\
10 & 165 & -2.6556 & 1.165 & -2.0001 & 6.9019 & 0.2262 \\
15 & 230 & -2.5984 & 1.1191 & -2.0217 & 4.99 & 0.2262 \\
20 & 244 & -2.5411 & 1.1133 & -2.084 & 5.6697 & 0.2239 \\
30 & 256 & -2.6027 & 1.1155 & -2.0144 & 4.195 & 0.2208 \\
50 & 269 & -2.3774 & 1.0868 & -2.2392 & 6.6336 & 0.2336 \\
100 & 280 & -2.3652 & 1.0818 & -2.2476 & 5.7368 & 0.2399 \\
100 & $288^{*}$ & -2.3601 & 1.0741 & -2.2457 & 5.2665 & 0.2529 \\
\hline
\end{tabular}

*)including stronger events recorded prior to MSHTP project

Table 3

Coefficients of the GMPE Eq. 2

calculated for events within different distances to the epicenter

\begin{tabular}{|c|c|c|c|c|c|c|}
\hline Distance limit & Data points & $a_{1}$ & $a_{2}$ & $a_{4}$ & $h$ & $\sigma$ \\
\hline 5 & 88 & -3.0214 & 1.1784 & -0.0846 & 5.5441 & 0.2056 \\
10 & 165 & -2.8465 & 1.165 & -0.0779 & 9.225 & 0.2256 \\
15 & 230 & -3.217 & 1.1192 & -0.0429 & 3.7152 & 0.2262 \\
20 & 244 & -3.1949 & 1.1155 & -0.0445 & 3.9287 & 0.2229 \\
30 & 256 & -3.3544 & 1.1161 & -0.0301 & 2.2112 & 0.223 \\
50 & 269 & -3.3029 & 1.108 & -0.034 & 2.7008 & 0.2254 \\
100 & 280 & -3.4162 & 1.0913 & -0.0235 & 1.182 & 0.2456 \\
100 & $288^{*}$ & -3.4941 & 0.9547 & -0.0062 & 0 & 0.3342 \\
\hline
\end{tabular}

*)including stronger events recorded prior to MSHTP project

Finally, a model of the form of Eq. 1 obtained with TSR regression method $\left(a_{1}=-2.17, a_{2}=1.1, a_{3}=-2.4, h=4.87\right)$ was compared with other GMPE's. There was chosen an equation of Schenk et al. (2000) which was dedicated for the whole area of Czech, Poland, and Slovakia and five other equations used in the project SHARE (Delavaud et al. 2012) to describe central European region. An example plot for an event of magnitude $M_{w}=4$ is shown in Fig. 9. For small distances, our solution gives higher values than other models except the one by Campbell (2003), but for distances over $10 \mathrm{~km}$ from the epicenter it gives the highest values. The most probable rea- 


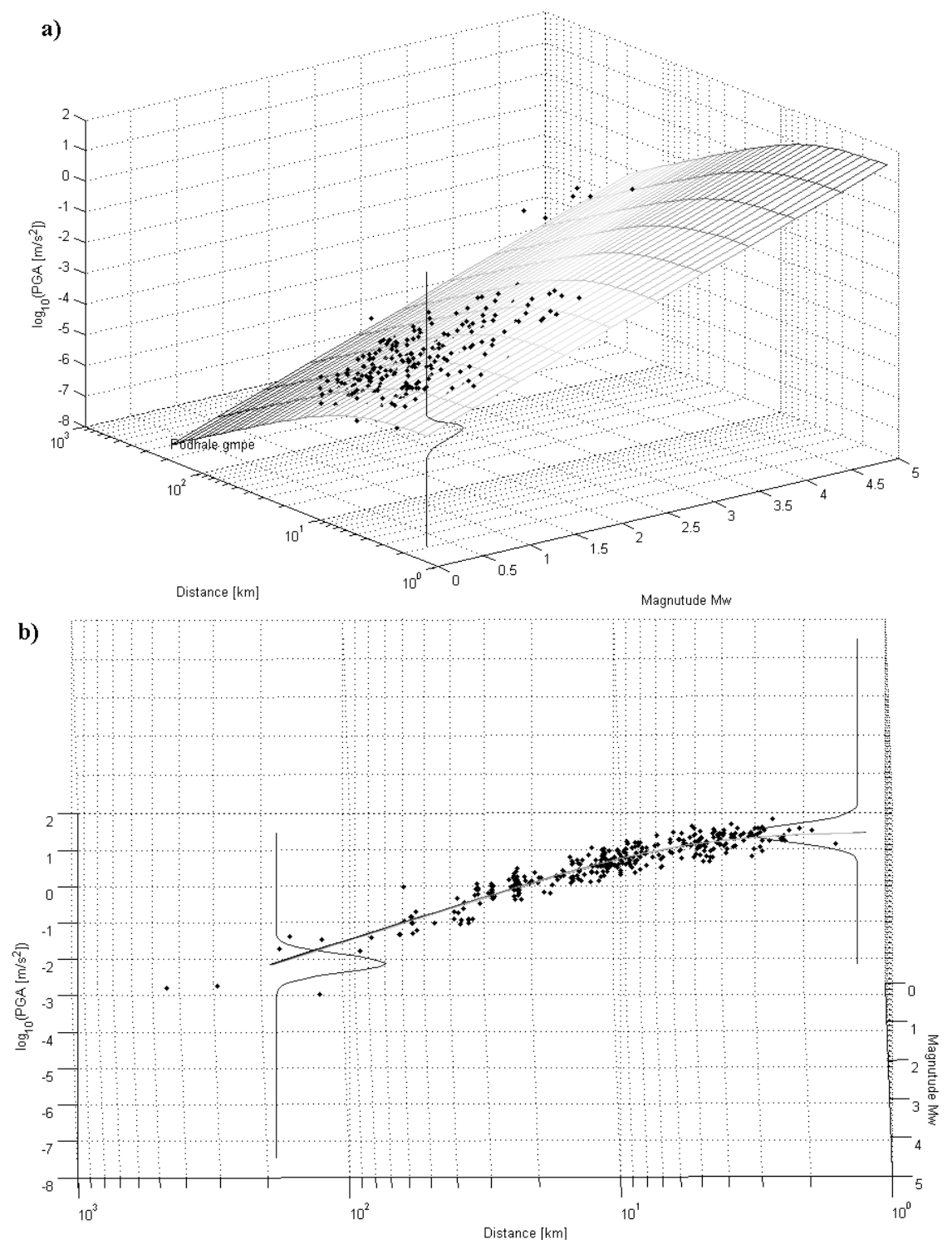

Fig. 8. TSR regression model as a surface in 3D plotted in two projections, (a) and (b), together with recorded peak horizontal acceleration - black dots. Uncertainty of the model is given by the probability distribution plotted in a vertical axis.

son for this difference from other models is that the majority of events in Podhale were of small magnitude and at small distance, which makes a weak fit for strong and distant events. To obtain a better GMPE for Podhale it is necessary to record stronger events with a wide spectrum of distances. 


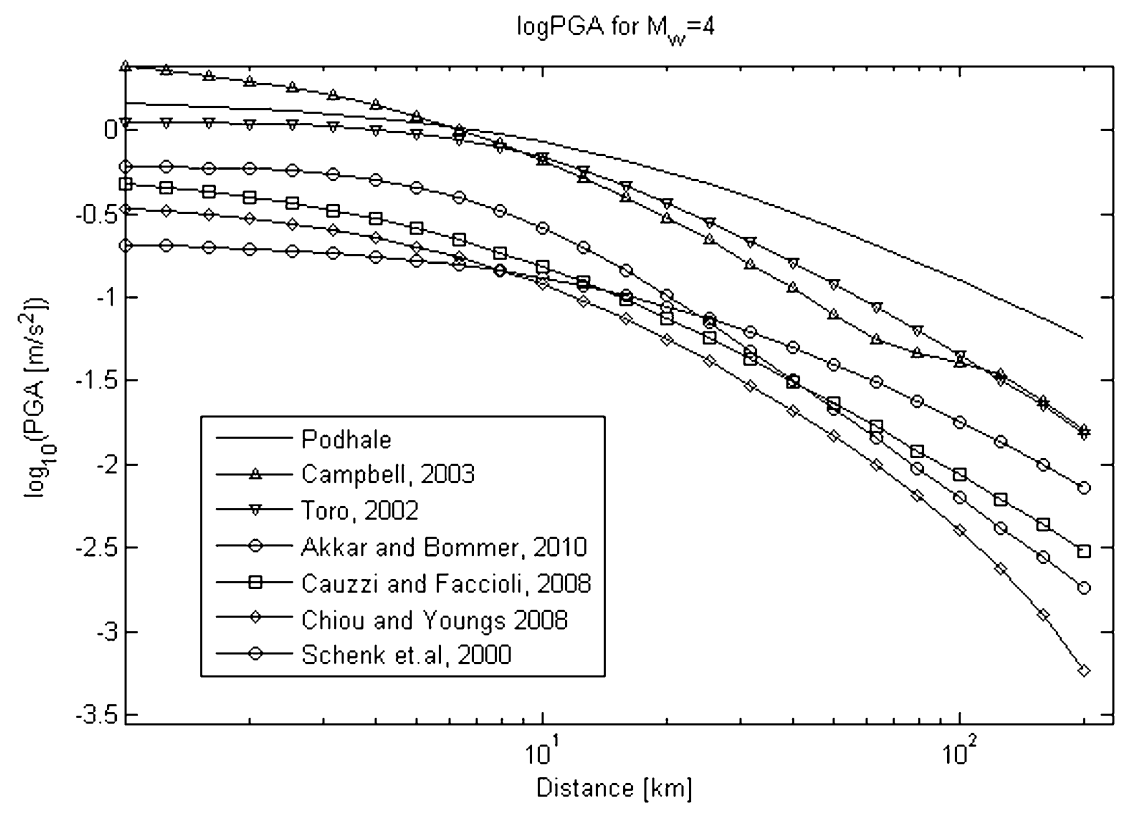

Fig. 9. Comparison of different GMPE's for an event with magnitude $M_{w}=4$.

\section{Non-seismic events}

When continuous measurements are carried out, there are many non-seismic events recorded by seismic stations. Usually they are local and are recorded only by one station, so they are not even detected by algorithms. Sometimes, such signals are recorded by more stations but still in one region. It can be, for example, a sonic wave caused by an explosion or a shock wave of a supersonic jet. It is easy to distinguish such an event from seismic one because it has much smaller propagation velocity.

An interesting event happened on 25 February 2011, but there were more very similar ones. A set of regularly spaced ( 2 min interval) impulses was recorded by some stations in very distant regions (over $300 \mathrm{~km}$ ). The best records for vertical components are presented in Fig. 10 and associated station locations in Fig. 11.

Joint epicenter location and velocity inversion derived a velocity of $\sim 350 \mathrm{~m} / \mathrm{s}$ which fits sonic wave speed very well. The locations obtained for the first impulse and the last impulse are almost the same and are very close to $\varphi=54.50 \mathrm{~N}, \lambda=20.83 \mathrm{E}$ (Fig. 11). This suggests that the source was immobile and was on the territory of Kaliningrad Oblast / Russia. It is still not clear what kind of source could generate such a signal. 


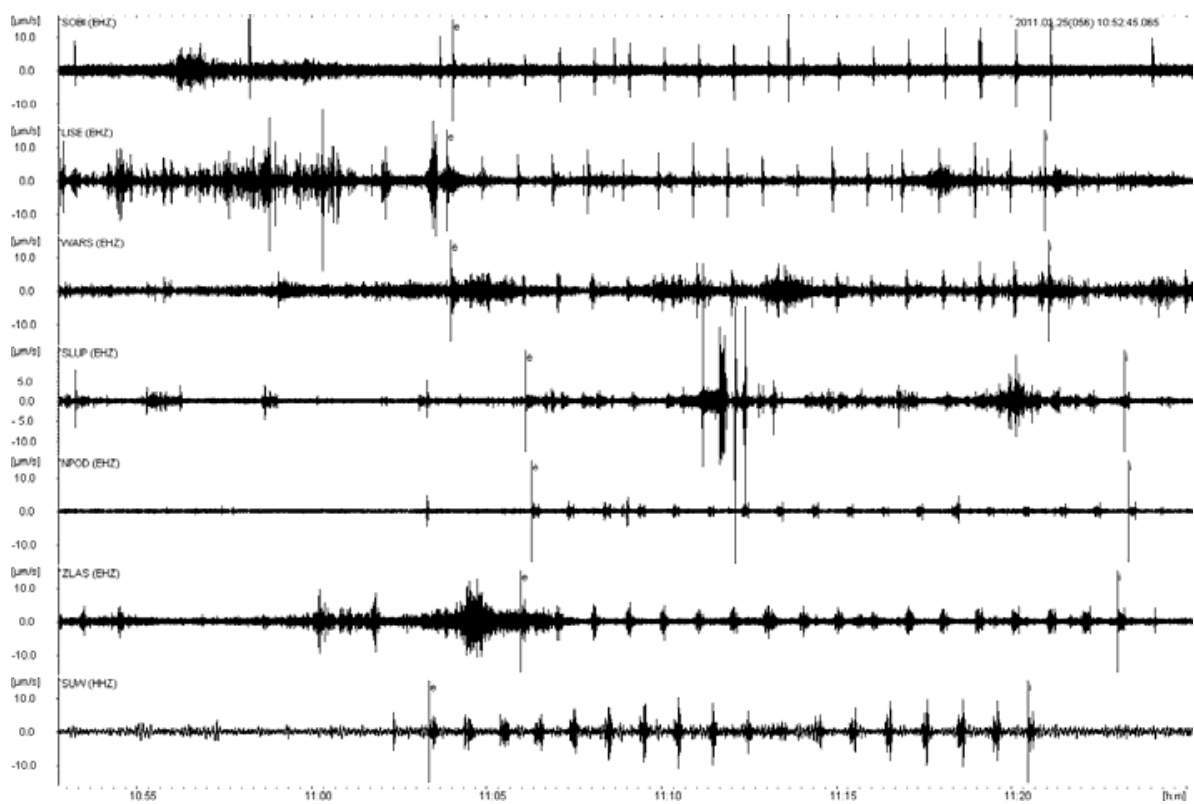

Fig. 10. Vertical components of stations: SOBI, LISE, WARS, SLUP, NPOD, ZLAS, SUW, which recorded the pulses in regular intervals in different regions of Poland. Delays between stations indicate much slower propagation than for seismic waves. First pulse on each seismogram is marked with "e" and the last one with "i".

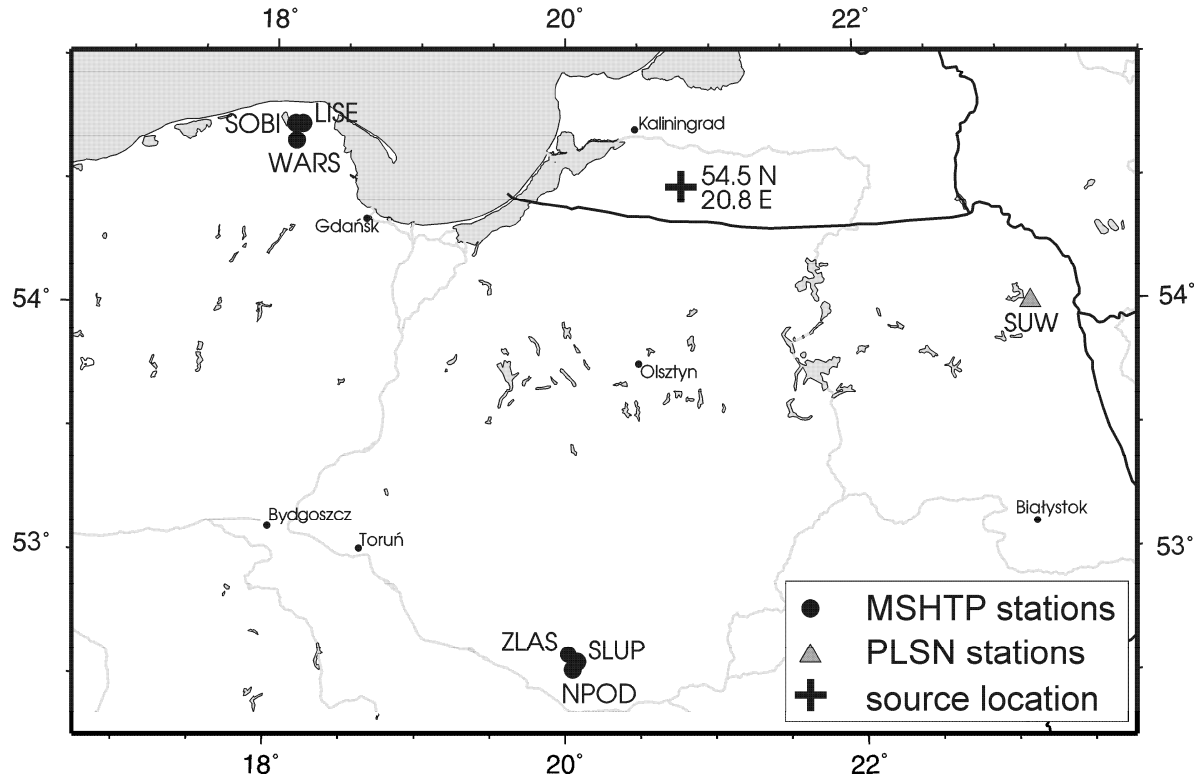

Fig. 11. Distribution of stations presented in Fig. 10 (circles) and source location obtained jointly with velocity inversion (cross). 


\section{CONCLUSIONS}

"Monitoring of Seismic Hazard of Territory of Poland" was the first project of this scale in Poland that focused on local natural seismicity. The existing seismological network ( 9 stations) is meant for global and regional scale monitoring measurements. It is not capable to detect and locate events smaller than magnitude 3. A new seismic network composed of 24 mobile seismic stations significantly improved this sensitivity. Together with new seismic stations a new acquisition system was set up and new tools for maintaining a network and for data processing were developed, which makes a room for a further network growth.

Monitored regions were selected on the basis of analysis of historical seismicity and were scattered over the area of Poland. A five-year project confirmed seismic activity of the Carpathians (Stage 1, Region A, and Stage 2, Region I, Figs. 2 and 3), mainly in the Podhale region, where over 100 events have been recorded, and near Krynica / Beskid Sądecki / Carpathians (three events). At the beginning of the project both places have been already known for historical earthquakes and recent seismic activity. Second region with a surprisingly large earthquake is near Jarocin / Wielkopolska / western Poland (Stage 2, Region E, Fig. 3). This region was not considered as a potential source of such earthquake and was not covered by monitoring before the earthquake occurrence.

In other mountain regions, Sudetes (Stage 1, Region A, Fig. 2) and Holy Cross Mountains (Stage 2, Region H, Fig. 3), there has not been recorded any natural seismic event, which suggests that return period of detectable events is too long comparing to the monitoring period. This argument is valid for other regions as well, but bad recording conditions additionally reduce the detection possibility. The best recording conditions, in terms of noise level, are in mountains in the south, where sediments are very thin and it is often possible to put a seismometer directly on a rock. Much greater noise, by about two orders of the PSD magnitude, is in regions of sedimentary background (Stage 2, Regions C-G, Fig. 3).

The number of events in the Podhale region made it possible to conduct a preliminary study on ground motion prediction equation for this region, which is a key for future seismic hazard assessments. The obtained equation fits the data well but there is a lack of strong motion records, which makes the solution less adequate for higher magnitudes.

The project confirmed that some regions of Poland are seismically active, which makes them interesting objects of future studies. It was also proved that applied mobile monitoring network is a reliable and adequate tool for measurements of this type. 
Acknowledgments. The project "Monitoring of Seismic Hazard of Territory of Poland" (MSHTP) was carried out by the Institute of Geophysics, Polish Academy of Sciences, in the period 2007-2012 on the order of the Ministry of the Environment and financed from funds of the National Fund for Environmental Protection and Water Management (contract No. 445/ 2007/Wn-07/F6-bp-tx/D).

\section{Appendix 1}

\section{List of stations in the project}

\begin{tabular}{|c|c|c|c|c|c|c|c|}
\hline $\begin{array}{l}\text { Station } \\
\text { name }\end{array}$ & Stage & Site name & Recording period & $\begin{array}{l}\text { Lat. } \\
{\left[{ }^{\circ}\right] \mathrm{N}}\end{array}$ & $\begin{array}{l}\text { Long. } \\
{\left[{ }^{\circ}\right] \mathrm{E}}\end{array}$ & $\begin{array}{l}\text { Elev. } \\
{[\mathrm{m}]}\end{array}$ & Region \\
\hline AWRA & 1 & Ciche & $\begin{array}{l}17 \text { Jun } 2008- \\
10 \text { Aug } 2008\end{array}$ & 49.40 & 19.87 & 670 & B \\
\hline BLAT & 1 & Błatnia & $\begin{array}{c}6 \text { May } 2009- \\
2 \text { Oct } 2009\end{array}$ & 49.75 & 18.94 & 887 & B \\
\hline BOBR & 1 & Bóbrka & $\begin{array}{l}9 \text { Sep } 2008- \\
19 \text { May } 2010\end{array}$ & 49.62 & 21.71 & 334 & B \\
\hline $\mathrm{CICH}$ & $1+2$ & Ciche & $\begin{array}{l}11 \text { Aug } 2008- \\
\text { 31 Dec } 2012\end{array}$ & 49.39 & 19.87 & 670 & $\mathrm{~B}, \mathrm{I}$ \\
\hline CISO & 2 & Cisów & $\begin{array}{l}13 \text { Jul } 2010- \\
31 \text { Dec } 2012\end{array}$ & 50.77 & 20.90 & 331 & $\mathrm{H}$ \\
\hline DEBO & 1 & Dębowiec & \begin{tabular}{|c|}
23 Sep $2008-$ \\
1 Dec 2008 \\
\end{tabular} & 50.59 & 17.11 & 278 & A \\
\hline DOMA & 2 & Domatowo & $\begin{array}{l}28 \text { Jul } 2010- \\
\quad 31 \text { Dec } 2012\end{array}$ & 54.71 & 18.21 & 103 & $\mathrm{D}$ \\
\hline DUKL & 1 & Dukla & $\begin{array}{r}19 \text { Jun } 2008- \\
6 \text { Aug } 2008\end{array}$ & 49.52 & 21.68 & 502 & B \\
\hline DZIA & 2 & Dzianisz & $\begin{array}{r}27 \text { Oct } 2010- \\
31 \text { Dec } 2012\end{array}$ & 49.32 & 19.84 & 921 & I \\
\hline FLOR & 1 & Florynka & $\begin{array}{c}18 \text { Jun } 2008- \\
4 \text { Sep } 2008\end{array}$ & 49.55 & 20.98 & 403 & B \\
\hline GLAD & 1 & Gładyszów & $\begin{array}{r}26 \text { Oct } 2009- \\
9 \text { Jan } 2010\end{array}$ & 49.53 & 21.29 & 521 & B \\
\hline GLIN & 1 & Glinka & $\begin{array}{r}17 \text { Sep } 2009- \\
14 \text { Apr } 2010\end{array}$ & 49.46 & 19.18 & 673 & B \\
\hline HOLU & 1 & Hołuczków & $\begin{array}{c}17 \text { Jul } 2008- \\
8 \text { Jun } 2010\end{array}$ & 49.58 & 22.33 & 381 & $\mathrm{~B}$ \\
\hline
\end{tabular}


continuation

\begin{tabular}{|c|c|c|c|c|c|c|c|}
\hline $\begin{array}{l}\text { Station } \\
\text { name }\end{array}$ & Stage & Site name & Recording period & $\begin{array}{l}\text { Lat. } \\
{\left[{ }^{\circ}\right] \mathrm{N}}\end{array}$ & $\begin{array}{l}\text { Long. } \\
{\left[{ }^{\circ}\right] \mathrm{E}}\end{array}$ & $\begin{array}{c}\text { Elev. } \\
{[\mathrm{m}]}\end{array}$ & Region \\
\hline HORD & 2 & Hordzieszka & $\begin{array}{l}7 \text { Jul } 2010- \\
21 \text { Oct } 2010 \\
\end{array}$ & 51.74 & 22.18 & 175 & G \\
\hline JAR1 & 2 & Mniszew & $\begin{array}{l}8 \text { Jan } 2010- \\
31 \text { Dec } 2012 \\
\end{array}$ & 52.04 & 17.69 & 81 & $\mathrm{E}$ \\
\hline JAR2 & 2 & Stęgosz & $\begin{array}{l}8 \text { Jan } 2010- \\
31 \text { Dec } 2012\end{array}$ & 52.04 & 17.52 & 97 & $\mathrm{E}$ \\
\hline JAR3 & 2 & Ludwinów & $\begin{array}{l}\text { Jan } 2010- \\
31 \text { Dec } 2012\end{array}$ & 52.05 & 17.62 & 82 & $\mathrm{E}$ \\
\hline JAR4 & 2 & Pogorzelica & $\begin{array}{l}\text { Jan } 2010- \\
31 \text { Dec } 2012 \\
\end{array}$ & 52.14 & 17.59 & 71 & $\mathrm{E}$ \\
\hline JAR6 & 2 & Lgów & $\begin{array}{l}\text { Jan } 2010- \\
31 \text { Dec } 2012\end{array}$ & 52.10 & 17.53 & 72 & $\mathrm{E}$ \\
\hline JAWO & 1 & $\begin{array}{c}\text { Jaworki - } \\
\text { Biała Woda }\end{array}$ & $\begin{array}{l}18 \text { Jun } 2008- \\
20 \text { Jul } 2008\end{array}$ & 49.41 & 20.57 & 616 & $\mathrm{~B}$ \\
\hline JELE & 2 & Jeleniów & $\begin{array}{l}27 \text { Oct } 2010- \\
31 \text { Dec } 2012\end{array}$ & 50.83 & 21.13 & 347 & $\mathrm{H}$ \\
\hline KLET & 1 & Kletno & $\begin{array}{l}2 \text { Dec } 2008- \\
15 \text { Dec } 2008\end{array}$ & 50.25 & 16.84 & 878 & A \\
\hline KONO & 2 & Konorzatka & $\begin{array}{l}7 \text { Jul } 2010- \\
31 \text { Dec } 2012\end{array}$ & 51.71 & 22.24 & 158 & G \\
\hline KRAS & 2 & $\begin{array}{c}\text { Kraśnik } \\
\text { Koszaliński }\end{array}$ & $\begin{array}{l}23 \text { Aug } 2010- \\
\text { 31 Dec } 2012\end{array}$ & 54.13 & 15.99 & 30 & $\mathrm{C}$ \\
\hline LABO & 1 & Łabowa & $\begin{array}{r}10 \text { Sep } 2008- \\
19 \text { May } 2010\end{array}$ & 49.52 & 20.83 & 509 & $\mathrm{~B}$ \\
\hline LE01 & 2 & $\begin{array}{l}\text { Karlikowo } \\
\text { Leborskie }\end{array}$ & $\begin{array}{l}12 \text { Jul } 2011- \\
4 \text { Oct } 2011\end{array}$ & 54.64 & 17.78 & 73 & $\mathrm{D}$ \\
\hline LE02 & 2 & $\begin{array}{c}\text { Rekowo } \\
\text { Leborskie }\end{array}$ & $\begin{array}{l}13 \text { Jul } 2011- \\
4 \text { Oct } 2012\end{array}$ & 54.63 & 17.79 & 66 & $\mathrm{D}$ \\
\hline LE03 & 2 & Obliwice & $\begin{array}{r}14 \text { Jul } 2011- \\
7 \text { Oct } 2013\end{array}$ & 54.62 & 17.74 & 56 & $\mathrm{D}$ \\
\hline LE04 & 2 & Lebien & $\begin{array}{l}\text { 14 Jul } 2011- \\
4 \text { Oct } 2014\end{array}$ & 54.64 & 17.72 & 50 & $\mathrm{D}$ \\
\hline LE05 & 2 & Basewice & $\begin{array}{l}20 \text { Jul } 2011- \\
25 \text { Sep } 2015\end{array}$ & 54.67 & 17.79 & 69 & $\mathrm{D}$ \\
\hline LE06 & 2 & $\begin{array}{c}\text { Krepa } \\
\text { Kaszubska }\end{array}$ & $\begin{array}{l}21 \text { Jul } 2011- \\
7 \text { Oct } 2016\end{array}$ & 54.63 & 17.66 & 73 & $\mathrm{D}$ \\
\hline
\end{tabular}




\begin{tabular}{|c|c|c|c|c|c|c|c|}
\hline $\begin{array}{l}\text { Station } \\
\text { name }\end{array}$ & Stage & Site name & Recording period & $\begin{array}{l}\text { Lat. } \\
{\left[{ }^{\circ}\right] \mathrm{N}}\end{array}$ & $\begin{array}{l}\text { Long. } \\
{\left[{ }^{\circ}\right] \mathrm{E}}\end{array}$ & $\begin{array}{c}\text { Elev. } \\
{[\mathrm{m}]}\end{array}$ & Region \\
\hline LE07 & 2 & Niebedzino & $\begin{array}{l}21 \text { Jul } 2011- \\
7 \text { Oct } 2017\end{array}$ & 54.57 & 17.62 & 55 & $\mathrm{D}$ \\
\hline LE08 & 2 & Lubowidz & $\begin{array}{r}21 \text { Jul } 2011- \\
7 \text { Oct } 2017 \\
\end{array}$ & 54.54 & 17.81 & 29 & $\mathrm{D}$ \\
\hline LE09 & 2 & Leczyn Dolny & $\begin{array}{r}22 \text { Jul } 2011- \\
6 \text { Oct } 2019 \\
\end{array}$ & 54.64 & 17.95 & 125 & $\mathrm{D}$ \\
\hline LISE & 2 & Lisewo & $\begin{array}{l}28 \text { Jul } 2010- \\
31 \text { Dec } 2012\end{array}$ & 54.75 & 18.18 & 25 & $\mathrm{D}$ \\
\hline LULE & 2 & Lulewice & $\begin{array}{r}14 \text { Jul } 2010- \\
31 \text { Dec } 2012\end{array}$ & 54.05 & 15.95 & 24 & $\mathrm{C}$ \\
\hline LUTW & 1 & Lutowiska & $\begin{array}{r}18 \text { Jul } 2008- \\
31 \text { May } 2010 \\
\end{array}$ & 49.24 & 22.69 & 650 & $\mathrm{~B}$ \\
\hline MAKO & 2 & Lechów & $\begin{array}{l}13 \text { Jul } 2010- \\
31 \text { Dec } 2012\end{array}$ & 50.81 & 21.00 & 334 & $\mathrm{H}$ \\
\hline MERZ & 2 & Mierzynek & $\begin{array}{l}13 \text { Jul } 2010- \\
31 \text { Dec } 2012 \\
\end{array}$ & 54.10 & 15.90 & 32 & $\mathrm{C}$ \\
\hline MNIS & 1 & Mniszków & $\begin{array}{r}9 \text { Aug } 2008- \\
31 \text { May } 2010 \\
\end{array}$ & 50.86 & 15.94 & 626 & A \\
\hline NOSO & 2 & Nosówko & $\begin{array}{l}13 \text { Jul } 2010- \\
23 \text { Aug } 2010 \\
\end{array}$ & 54.10 & 16.00 & 29 & $\mathrm{C}$ \\
\hline NPOD & 2 & $\begin{array}{c}\text { Nowy } \\
\text { Podleck }\end{array}$ & $\begin{array}{c}23 \text { Aug } 2010- \\
6 \text { Jan } 2012 \\
\end{array}$ & 52.55 & 20.05 & 127 & $\mathrm{~F}$ \\
\hline OCIE & 2 & Ociesęki & $\begin{array}{l}13 \text { Jul } 2010- \\
31 \text { Dec } 2012\end{array}$ & 50.73 & 20.97 & 312 & $\mathrm{H}$ \\
\hline OSIE & 1 & $\begin{array}{c}\text { Osiek } \\
\text { Jasielski }\end{array}$ & $\begin{array}{r}19 \text { Jun } 2008- \\
3 \text { Sep } 2008\end{array}$ & 49.64 & 21.49 & 226 & $\mathrm{~B}$ \\
\hline OSIN & 1 & Osina Wielka & $\begin{array}{r}8 \text { Aug } 2008- \\
4 \text { Sep } 2008 \\
\end{array}$ & 50.58 & 17.07 & 229 & $\mathrm{~B}$ \\
\hline PAGO & 1 & Pagorzyna & $\begin{array}{l}9 \text { Sep } 2008- \\
27 \text { May } 2010\end{array}$ & 49.69 & 21.33 & 360 & $\mathrm{~B}$ \\
\hline PLUC & 2 & Płucki & $\begin{array}{l}25 \text { Oct } 2010- \\
31 \text { Dec } 2012\end{array}$ & 50.80 & 21.07 & 315 & $\mathrm{H}$ \\
\hline POTK & 2 & Potok & $\begin{array}{r}26 \text { Oct } 2010- \\
31 \text { Dec } 2012 \\
\end{array}$ & 49.36 & 20.16 & 886 & $\mathrm{I}$ \\
\hline PUS2 & 2 & Pustkowo & $\begin{array}{l}23 \text { Aug } 2010- \\
31 \text { Dec } 2012\end{array}$ & 54.08 & 16.04 & 20 & $\mathrm{C}$ \\
\hline
\end{tabular}




\begin{tabular}{|c|c|c|c|c|c|c|c|}
\hline $\begin{array}{l}\text { Station } \\
\text { name }\end{array}$ & Stage & Site name & Recording period & $\begin{array}{l}\text { Lat. } \\
{\left[{ }^{\circ}\right] \mathrm{N}}\end{array}$ & $\begin{array}{l}\text { Long. } \\
{\left[{ }^{\circ}\right] \mathrm{E}}\end{array}$ & $\begin{array}{c}\text { Elev. } \\
{[\mathrm{m}]}\end{array}$ & Region \\
\hline PUST & 2 & Pustkowo & $\begin{array}{l}27 \text { Jul } 2010- \\
23 \text { Aug } 2010\end{array}$ & 54.06 & 16.03 & 19 & $\mathrm{C}$ \\
\hline RACL & 1 & Racławice & $\begin{array}{l}7 \text { Aug } 2008- \\
30 \text { Aug } 2008\end{array}$ & 49.75 & 21.18 & 342 & $\mathrm{~B}$ \\
\hline ROPK & 1 & Ropki & $\begin{array}{l}9 \text { Aug } 2008- \\
1 \text { Jun } 2010\end{array}$ & 49.46 & 21.13 & 563 & $\mathrm{~B}$ \\
\hline $\mathrm{RYC} 2$ & 1 & Rychwałdek & $\begin{array}{r}5 \text { May } 2009- \\
17 \text { May } 2010\end{array}$ & 49.68 & 19.28 & 464 & $\mathrm{~B}$ \\
\hline $\mathrm{RYCH}$ & 1 & Rychwałdek & $\begin{array}{l}1 \text { Nov } 2008- \\
5 \text { May } 2009\end{array}$ & 49.68 & 19.28 & 493 & $\mathrm{~B}$ \\
\hline RZEP & 1 & Rzepedź & $\begin{array}{l}19 \text { Jul } 2008- \\
31 \text { May } 2010\end{array}$ & 49.39 & 22.10 & 458 & $\mathrm{~B}$ \\
\hline SCWK & 1 & Szczawnik & $\begin{array}{r}9 \text { Aug } 2008- \\
29 \text { Oct } 2008\end{array}$ & 49.38 & 20.87 & 523 & $\mathrm{~B}$ \\
\hline SEDK & 2 & Sędek & $\begin{array}{l}13 \text { Jul } 2010- \\
31 \text { Dec } 2012\end{array}$ & 50.77 & 21.01 & 396 & $\mathrm{H}$ \\
\hline SIER & $1+2$ & Sierockie & $\begin{array}{l}11 \text { Aug } 2008- \\
31 \text { Dec } 2012\end{array}$ & 49.36 & 19.96 & 1007 & $\mathrm{~B}, \mathrm{I}$ \\
\hline SKAW & 1 & Skawica & $\begin{array}{r}20 \text { Jul } 2008- \\
12 \text { May } 2010\end{array}$ & 49.65 & 19.66 & 686 & B \\
\hline SLUP & 2 & Słupca & $\begin{array}{l}1 \text { Jul } 2010- \\
6 \text { Jan } 2012\end{array}$ & 52.58 & 20.08 & 139 & $\mathrm{~F}$ \\
\hline SOBI & 2 & Sobieńczyce & $\begin{array}{r}28 \text { Jul } 2010- \\
31 \text { Dec } 2012\end{array}$ & 54.75 & 18.13 & 102 & $\mathrm{D}$ \\
\hline $\mathrm{SOCH}$ & 2 & $\begin{array}{l}\text { Sochocino- } \\
\text { Praga }\end{array}$ & $\begin{array}{r}1 \text { Jul } 2010- \\
6 \text { Jan } 2012\end{array}$ & 52.57 & 19.98 & 129 & $\mathrm{~F}$ \\
\hline SPAL & 1 & Spalona & $\begin{array}{r}17 \text { Dec } 2008- \\
1 \text { Jun } 2010 \\
\end{array}$ & 50.28 & 16.54 & 760 & A \\
\hline SRGO & 1 & Srebrna Góra & $\begin{array}{r}8 \text { Aug } 2008- \\
1 \text { Jun } 2010 \\
\end{array}$ & 50.58 & 16.66 & 483 & A \\
\hline STBY & $1+2$ & Stare Bystre & $\begin{array}{l}20 \text { Jul } 2008- \\
31 \text { Dec } 2012 \\
\end{array}$ & 49.43 & 19.94 & 682 & $\mathrm{~B}, \mathrm{I}$ \\
\hline STRO & 1 & Stronie & $\begin{array}{r}13 \text { Sep } 2008- \\
1 \text { Jun } 2010\end{array}$ & 49.62 & 20.53 & 578 & $\mathrm{~B}$ \\
\hline SWIA & 1 & $\begin{array}{l}\text { Świątkowa } \\
\text { Wielka }\end{array}$ & $\begin{array}{r}8 \text { Aug } 2008- \\
4 \text { Sep } 2008\end{array}$ & 49.54 & 21.42 & 444 & $\mathrm{~B}$ \\
\hline
\end{tabular}




\begin{tabular}{|c|c|c|c|c|c|c|c|}
\hline $\begin{array}{l}\text { Station } \\
\text { name }\end{array}$ & Stage & Site name & Recording period & $\begin{array}{l}\text { Lat. } \\
{\left[{ }^{\circ}\right] \mathrm{N}}\end{array}$ & $\begin{array}{c}\text { Long. } \\
{\left[^{\circ}\right] \mathrm{E}}\end{array}$ & $\begin{array}{c}\text { Elev. } \\
{[\mathrm{m}]}\end{array}$ & Region \\
\hline SWKR & 2 & Święty Krzyż & $\begin{array}{r}25 \text { Oct } 2010- \\
31 \text { Dec } 2012\end{array}$ & 50.86 & 21.05 & 556 & $\mathrm{H}$ \\
\hline SZCZ & 2 & Szczałb & $\begin{array}{l}7 \text { Jul } 2010- \\
21 \text { Oct } 2010 \\
\end{array}$ & 51.77 & 22.24 & 159 & G \\
\hline SZKL & 1 & Szklary & $\begin{array}{r}7 \text { Aug } 2008- \\
31 \text { May } 2010 \\
\end{array}$ & 49.47 & 21.81 & 559 & A \\
\hline WARS & 2 & Warszkowo & $\begin{array}{l}28 \text { Jul } 2010- \\
31 \text { Dec } 2012\end{array}$ & 54.68 & 18.14 & 43 & $\mathrm{D}$ \\
\hline WILC & 1 & Wilczyce & $\begin{array}{r}11 \text { Aug } 2008- \\
31 \text { May } 2010 \\
\end{array}$ & 49.67 & 20.18 & 615 & B \\
\hline WRZO & 1 & Wrzosówka & $\begin{array}{r}7 \text { Aug } 2008- \\
1 \text { Jun } 2010 \\
\end{array}$ & 50.38 & 16.90 & 722 & A \\
\hline ZAGR & 1 & Zagórze & $\begin{array}{l}21 \text { Jul } 2008- \\
16 \text { Jun } 2010\end{array}$ & 49.83 & 19.55 & 337 & $\mathrm{~B}$ \\
\hline ZAKE & 2 & Zakępie & $\begin{array}{l}7 \text { Jul } 2010- \\
21 \text { Oct } 2010\end{array}$ & 51.73 & 22.30 & 158 & G \\
\hline ZAWO & 1 & Zawoja & $\begin{array}{l}17 \text { Jun } 2008- \\
20 \text { Jul } 2008 \\
\end{array}$ & 49.64 & 19.53 & 613 & $\mathrm{~B}$ \\
\hline ZDYN & 1 & Zdynia & $\begin{array}{r}30 \text { Sep } 2009- \\
26 \text { Oct } 2009 \\
\end{array}$ & 49.49 & 21.27 & 521 & $\mathrm{~B}$ \\
\hline ZDZW & 2 & Zdziar Wielki & \begin{tabular}{|} 
2 Jul $2010-$ \\
23 Aug 2010 \\
\end{tabular} & 52.63 & 20.05 & 134 & $\mathrm{~F}$ \\
\hline ZEGI & 1 & Żegiestów & $\begin{array}{r}29 \text { Oct } 2008- \\
31 \text { May } 2010 \\
\end{array}$ & 49.37 & 20.79 & 466 & $\mathrm{~B}$ \\
\hline ZLAS & 2 & Zdziar Las & $\begin{array}{r}23 \text { Aug } 2010- \\
6 \text { Jan } 2012 \\
\end{array}$ & 52.61 & 20.02 & 146 & $\mathrm{~F}$ \\
\hline $\mathrm{ZOCH}$ & 2 & Żochocino & $\begin{array}{l}1 \text { Jul } 2010- \\
23 \text { Aug } 2010\end{array}$ & 52.63 & 20.12 & 127 & $\mathrm{~F}$ \\
\hline
\end{tabular}


Appendix 2

\section{List of events localized in Podhale/Carpathians} during MSHTP project

\begin{tabular}{|c|c|c|c|c|c|c|}
\hline No. & Date & Time & $\begin{array}{c}\text { Latitude } \\
{\left[{ }^{\circ} \mathrm{N}\right]}\end{array}$ & $\begin{array}{c}\text { Longitude } \\
{\left[{ }^{\circ} \mathrm{E}\right]}\end{array}$ & $\begin{array}{c}\text { Depth } \\
{[\mathrm{km}]}\end{array}$ & $M_{L}$ \\
\hline 1 & 5 Jul 2008 & $20: 11: 10.7$ & 49.320 & 19.742 & 5 & 1.6 \\
\hline 2 & 6 Jul 2008 & $11: 58: 11.5$ & 49.354 & 19.780 & 7 & 1.5 \\
\hline 3 & 5 Aug 2008 & $12: 28: 54.5$ & 49.405 & 20.142 & 4 & 2.5 \\
\hline 4 & 21 Sep 2008 & $16: 05: 23.8$ & 49.356 & 20.013 & 3 & 0.4 \\
\hline 5 & 10 Nov 2008 & $07: 55: 45.1$ & 49.385 & 20.084 & 3 & 1.1 \\
\hline 6 & 16 Dec 2008 & $23: 31: 54.9$ & 49.373 & 20.012 & 4 & 1.6 \\
\hline 7 & 12 Feb 2009 & $15: 20: 25.5$ & 49.321 & 19.916 & 5 & 0.9 \\
\hline 8 & 10 Apr 2009 & $17: 45: 39.1$ & 49.379 & 19.917 & 3 & 2.0 \\
\hline 9 & 10 Apr 2009 & 19:00:51.6 & 49.391 & 19.904 & 4 & 1.3 \\
\hline 10 & 12 Apr 2009 & $00: 27: 31.2$ & 49.391 & 19.910 & 6 & 0.5 \\
\hline 11 & 30 Apr 2009 & $05: 44: 31.2$ & 49.388 & 19.916 & 4 & 0.5 \\
\hline 12 & 29 May 2009 & $14: 57: 24.4$ & 49.317 & 19.690 & 3 & 2.1 \\
\hline 13 & 29 May 2009 & $20: 33: 28.3$ & 49.344 & 19.878 & 1 & 1.0 \\
\hline 14 & 13 Aug 2009 & $19: 47: 23.9$ & 49.384 & 19.834 & 3 & 1.7 \\
\hline 15 & 29 Aug 2009 & $23: 20: 19.9$ & 49.384 & 19.846 & 3 & 0.9 \\
\hline 16 & 3 Sep 2009 & $20: 40: 52.7$ & 49.392 & 19.835 & 3 & 0.9 \\
\hline 17 & 7 Sep 2009 & $16: 52: 39.7$ & 49.401 & 20.015 & 3 & 1.6 \\
\hline 18 & 1 Oct 2009 & 07:06:41.7 & 49.393 & 19.903 & 3 & 0.8 \\
\hline 19 & 4 Oct 2009 & $00: 32: 59.4$ & 49.393 & 19.904 & 4 & 0.8 \\
\hline 20 & 4 Oct 2009 & $23: 50: 21.9$ & 49.308 & 19.975 & 3 & 0.8 \\
\hline 21 & 16 Oct 2009 & $04: 22: 33.4$ & 49.368 & 19.884 & 3 & 0.9 \\
\hline 22 & 28 Oct 2009 & $22: 00: 28.2$ & 49.331 & 19.924 & 8 & 0.6 \\
\hline 23 & 12 Nov 2009 & $14: 38: 18.3$ & 49.320 & 19.976 & 3 & 0.9 \\
\hline 24 & 15 Dec 2009 & $11: 46: 51.3$ & 49.332 & 19.916 & 7 & 1.9 \\
\hline 25 & 19 Mar 2010 & 07:18:54.9 & 49.380 & 19.904 & 4 & 0.3 \\
\hline 26 & 31 Mar 2010 & 04:09:01.9 & 49.384 & 19.907 & 4 & 1.1 \\
\hline 27 & 3 Apr 2010 & $20: 28: 21.1$ & 49.312 & 19.970 & 5 & 1.0 \\
\hline 28 & 4 Apr 2010 & $07: 18: 33.6$ & 49.406 & 19.851 & 4 & 0.7 \\
\hline 29 & 7 May 2010 & 20:50:00.4 & 49.367 & 19.885 & 4 & 1.8 \\
\hline 30 & 13 May 2010 & $19: 02: 02.7$ & 49.396 & 19.921 & 5 & 1.3 \\
\hline 31 & 11 Aug 2010 & 05:05:49.6 & 49.392 & 19.910 & 4 & 0.7 \\
\hline
\end{tabular}




\begin{tabular}{|c|c|c|c|c|c|c|}
\hline No. & Date & Time & $\begin{array}{c}\text { Latitude } \\
{\left[{ }^{\circ} \mathrm{N}\right]}\end{array}$ & $\begin{array}{c}\text { Longitude } \\
{\left[{ }^{\circ} \mathrm{E}\right]}\end{array}$ & $\begin{array}{c}\text { Depth } \\
{[\mathrm{km}]}\end{array}$ & $M_{L}$ \\
\hline 32 & 1 Oct 2010 & $06: 31: 53.3$ & 49.389 & 19.912 & 3 & 1.8 \\
\hline 33 & 2 Oct 2010 & $23: 17: 54.9$ & 49.391 & 19.910 & 4 & 0.5 \\
\hline 34 & 7 Nov 2010 & 09:52:42.9 & 49.387 & 19.923 & 4 & 0.5 \\
\hline 35 & 8 Nov 2010 & $23: 16: 41.2$ & 49.376 & 19.884 & 5 & 0.6 \\
\hline 36 & 10 Nov 2010 & $00: 32: 52.9$ & 49.392 & 19.963 & 4 & 0.2 \\
\hline 37 & 19 Nov 2010 & $02: 56: 19.3$ & 49.398 & 19.924 & 5 & 0.2 \\
\hline 38 & 25 Jan 2011 & $02: 26: 28.5$ & 49.381 & 20.000 & 3 & 0.4 \\
\hline 39 & 8 Mar 2011 & 01:50:32.1 & 49.331 & 19.813 & 4 & 0.6 \\
\hline 40 & 28 Mar 2011 & $01: 53: 40.3$ & 49.332 & 19.828 & 5 & 0.9 \\
\hline 41 & 12 May 2011 & 01:38:58.2 & 49.291 & 20.119 & 3 & 0.7 \\
\hline 42 & 17 May 2011 & $20: 21: 50.8$ & 49.306 & 19.993 & 3 & 0.7 \\
\hline 43 & 21 May 2011 & 01:33:01.2 & 49.397 & 19.956 & 3 & 0.2 \\
\hline 44 & 21 Jun 2011 & $14: 54: 25.9$ & 49.418 & 19.829 & 4 & 1.4 \\
\hline 45 & $11 \mathrm{Jul} 2011$ & $21: 14: 07.8$ & 49.398 & 19.943 & 4 & 0.6 \\
\hline 46 & 11 Jul 2011 & $22: 06: 24.2$ & 49.280 & 19.774 & 5 & 0.8 \\
\hline 47 & 12 Jul 2011 & $02: 41: 53.8$ & 49.272 & 19.735 & 5 & 0.9 \\
\hline 48 & 12 Jul 2011 & $02: 54: 13.3$ & 49.267 & 19.762 & 5 & 0.6 \\
\hline 49 & 24 Jul 2011 & $03: 28: 57.3$ & 49.270 & 19.869 & 5 & 1.0 \\
\hline 50 & 26 Jul 2011 & $00: 53: 33.8$ & 49.296 & 19.746 & 5 & 0.5 \\
\hline 51 & 29 Jul 2011 & $20: 28: 58.8$ & 49.391 & 19.907 & 5 & 0.3 \\
\hline 52 & 22 Aug 2011 & $22: 20: 52.9$ & 49.374 & 20.072 & 2 & 0.4 \\
\hline 53 & 3 Sep 2011 & 19:20:09.7 & 49.370 & 19.889 & 2 & 0.2 \\
\hline 54 & 26 Sep 2011 & 03:48:16.9 & 49.374 & 20.018 & 4 & 0.3 \\
\hline 55 & 26 Sep 2011 & $16: 30: 54.8$ & 49.401 & 19.925 & 5 & 0.8 \\
\hline 56 & 26 Sep 2011 & $22: 23: 07.9$ & 49.392 & 19.934 & 4 & 0.4 \\
\hline 57 & 6 Oct 2011 & $23: 05: 21.8$ & 49.385 & 19.831 & 6 & 1.1 \\
\hline 58 & 6 Nov 2011 & $11: 35: 07.1$ & 49.366 & 19.834 & 5 & 0.5 \\
\hline 59 & 6 Nov 2011 & $13: 19: 37.6$ & 49.368 & 19.833 & 5 & 1.5 \\
\hline 60 & 26 Nov 2011 & $16: 31: 42.6$ & 49.386 & 19.910 & 3 & 2.1 \\
\hline 61 & 26 Nov 2011 & $18: 13: 37.1$ & 49.385 & 19.907 & 3 & 0.9 \\
\hline 62 & 15 Dec 2011 & 03:05:42.9 & 49.320 & 19.968 & 2 & 2.1 \\
\hline 63 & 15 Dec 2011 & $04: 56: 33.7$ & 49.318 & 19.968 & 2 & 1.3 \\
\hline 64 & 23 Dec 2011 & $17: 07: 03.8$ & 49.339 & 19.750 & 3 & 0.8 \\
\hline 65 & 8 Jan 2012 & $21: 45: 55.5$ & 49.283 & 19.946 & 3 & 0.6 \\
\hline 66 & 1 Mar 2012 & $19: 34: 38.3$ & 49.377 & 19.882 & 3 & 0.9 \\
\hline
\end{tabular}




\begin{tabular}{|c|c|c|c|c|c|c|}
\hline No. & Date & Time & $\begin{array}{c}\text { Latitude } \\
{\left[{ }^{\circ} \mathrm{N}\right]}\end{array}$ & $\begin{array}{c}\text { Longitude } \\
{\left[{ }^{\circ} \mathrm{E}\right]}\end{array}$ & $\begin{array}{c}\text { Depth } \\
{[\mathrm{km}]}\end{array}$ & $M_{L}$ \\
\hline 67 & 5 Mar 2012 & $14: 24: 45.6$ & 49.372 & 20.011 & 3 & 0.6 \\
68 & 8 Mar 2012 & $21: 33: 30.3$ & 49.379 & 20.019 & 3 & 0.5 \\
69 & 9 Jun 2012 & $03: 11: 50.2$ & 49.366 & 20.018 & 4 & 0.6 \\
70 & 6 Jul 2012 & $06: 18: 25.3$ & 49.397 & 19.950 & 4 & 1.2 \\
71 & 16 Jul 2012 & $09: 15: 28.6$ & 49.368 & 20.018 & 3 & 1.4 \\
72 & 17 Jul 2012 & $00: 47: 16.8$ & 49.369 & 20.015 & 4 & 0.7 \\
73 & 17 Jul 2012 & $05: 27: 13.0$ & 49.365 & 20.016 & 3 & 0.6 \\
74 & 17 Jul 2012 & $23: 15: 12.7$ & 49.369 & 20.014 & 4 & 0.4 \\
75 & 21 Jul 2012 & $22: 36: 52.9$ & 49.370 & 20.015 & 4 & 0.4 \\
76 & 25 Aug 2012 & $23: 27: 40.4$ & 49.407 & 19.948 & 4 & 0.6 \\
77 & 28 Sep 2012 & $17: 09: 34.2$ & 49.351 & 19.845 & 3 & 1.9 \\
78 & 16 Oct 2012 & $14: 35: 31.5$ & 49.365 & 20.015 & 3 & 0.8 \\
79 & 16 Oct 2012 & $14: 48: 30.0$ & 49.374 & 20.020 & 4 & 0.4 \\
80 & 4 Dec 2012 & $03: 57: 55.2$ & 49.392 & 19.924 & 4 & 0.6 \\
81 & 4 Dec 2012 & $13: 09: 30.9$ & 49.351 & 19.855 & 3 & 1.9 \\
\hline
\end{tabular}

\section{References}

Akkar, S., and J.J. Bommer (2010), Empirical equations for the prediction of PGA, PGV, and spectra accelerations in Europe, the Mediterranean Region, and the Middle East, Seismol. Res. Lett. 81, 2, 195-206, DOI: 10.1785/ gssrl.81. 2.195 .

Aleksandrowicz, D. (1982), Automatic seismic station ASS PCM 6/10, Acta Geophys. Pol. 30, 4, 381-392.

Andrews, D.J. (1986), Objective determination of source parameters and similarity of earthquakes of different size. In: S. Das, J. Boatwright, and C.H. Sholtz (eds.), Earthquake Source Mechanics, Geophysical Monograph, Vol. 37, American Geophysical Union, Washington, D.C., 259-267, DOI: 10.1029/ GM037p0259.

Brune, J.N. (1970), Tectonic stress and the spectra of seismic shear waves from earthquakes, J. Geophys. Res. 75, 26, 4997-5009, DOI: 10.1029/JB075i026 p04997.

Campbell, K.W. (2003), Prediction of strong ground motion using the hybrid empirical metod and its use in the development of ground-motion (attenuation) relations in eastern North America, Bull. Seismol. Soc. Am. 93, 3, 10121033, DOI: $10.1785 / 0120020002$. 
Cauzzi, C., and E. Faccioli (2008), Broadband (0.05 to $20 \mathrm{~s}$ ) prediction of displacement response spectra based on worldwide digital records, J. Seismol. 12, 4, 453-475, DOI: 10.1007/s10950-008-9098-y.

Chiou, B.S.-J., and R.R. Youngs (2008), An NGA model for the average horizontal component of peak ground motion and response spectra, Earthq. Spectra 24, 1, 173-215, DOI: 10.1193/1.2894832.

Delavaud, E., F. Cotton, S. Akkar, F. Scherbaum, L. Danciu, C. Beauval, S. Drouet, J. Douglas, R. Basili, M.A. Sandikkaya, M. Segou, E. Faccioli, and N. Theodoulidis (2012), Toward a ground-motion logic tree for probabilistic seismic hazard assessment in Europe, J. Seismol. 16, 3, 451-473, DOI: 10.1007/s10950-012-9281-z.

Domański, B.M. (2007), Source parameters of the 2004 Kaliningrad earthquakes, Acta Geophys. 55, 3, 267-287, DOI: 10.2478/s11600-007-0021-7.

Grad, M., A. Špičák, G.R. Keller, A. Guterch, M. Brož, E. Hegedüs, and Working Group (2003), SUDETES 2003 seismic experiment, Stud. Geophys. Geod. 47, 3, 681-689, DOI: 10.1023/A:1024732206210.

Guterch, A., M. Grad, H. Thybo, and G.R. Keller (1999), POLONAISE'97 - an international seismic experiment between Precambrian and Variscan Europe in Poland, Tectonophysics 314, 1-3, 101-121, DOI: 10.1016/S0040-1951 (99)00239-5.

Guterch, A., M. Grad, G.R. Keller, K. Posgay, J. Vozár, A. Špičák, E. Brückl, Z. Hajnal, H. Thybo, O. Selvi, and CELEBRATION 2000 Experiment Team (2003), CELEBRATION 2000 seismic experiment, Stud. Geophys. Geod. 47, 3, 659-669, DOI: 10.1023/A:1024728005301.

Guterch, B. (2006), Seismic events in the Orawa - Nowy Targ Basin, Western Carpathians, November 30, 2004 - December 2005, Acta Geodyn. Geomater. 3, 3, 85-95.

Guterch, B. (2007), Seismological Bulletin 2004, Local Earthquakes Recorded by Polish Seismological Stations, Publs. Inst. Geophys. Pol. Acad. Sci. B-40, 397.

Guterch, B. (2009), Seismicity in Poland in the light of historical records, Prz. Geol. 57, 6, 513-520 (in Polish).

Guterch, B., H. Lewandowska-Marciniak, and J. Niewiadomski (2005), Earthquakes recorded in Poland along the Pieniny Klippen Belt, Western Carpathians, Acta Geophys. Pol. 53, 1, 27-45.

Hościłowicz, M., J. Olszewski, and J. Wiszniowski (1990), Microcomputer seismic station MK-1, Acta Geophys. Pol. 38, 2, 141-147.

Idziak, A.F., and R. Dubiel (eds.) (2011), Geophysics in Mining and Enviromental Protection, Geoplanet: Earth and Planetary Sciences, Springer, Berlin Heidelberg, DOI: 10.1007/978-3-642-19097-1.

Joyner, W.B., and D.M. Boore (1993), Methods for regression analysis of strongmotion data, Bull. Seismol. Soc. Am. 83, 2, 469-487. 
Lizurek, G., and P. Wiejacz (2011), Moment tensor solution and physical parameters of selected recent seismic events at Rudna Copper Mine. In: A.F. Idziak and R. Dubiel (eds.), Geophysics in Mining and Environmental Protection, Geoplanet: Earth and Planetary Sciences, Springer, Berlin Heidelberg, 1119, DOI: 10.1007/978-3-642-19097-1_2.

Lizurek, G., B. Plesiewicz, P. Wiejacz, J. Wiszniowski, and J. Trojanowski (2013), Seismic event near Jarocin (Poland), Acta Geophys. 61, 1, 26-36, DOI: 10.2478/s11600-012-0052-6.

Olszewski, J., and J. Wiszniowski (1993), A microcomputer-based seismic station, Pol. Tech. Rev. 1, 18-21.

Orlecka-Sikora, B., S. Lasocki, G. Lizurek, and Ł. Rudziński (2012), Response of seismic activity in mines to the stress changes due to mining induced strong seismic events, Int. J. Rock Mech. Min. Sci. 53, 151-158, DOI: 10.1016/ j.ijrmms.2012.05.010.

Park, J., C.R. Lindberg, and F.L. Vernon III (1987), Multitaper spectral analysis of high-frequency seismograms, J. Geophys. Res. 92, B12, 12675-12684, DOI: $10.1029 / J B 092 \mathrm{iB} 12 \mathrm{p} 12675$.

Schenk, V., Z. Schenková, P. Kottnauer, B. Guterch, and P. Labák (2000), Earthquake hazard for the Czech Republic, Poland and Slovakia - Contribution to the ILC/IASPEI Global Seismic Hazard Assessment Program. In: G.A. Papadopoulos, T, Murty, S. Venkatesh, and R. Blong (eds.), Natural Hazards. State-of-the-Art at the End of the Second Millennium, Kluwer Academic Publ., Dordrecht, 331-345, DOI: 10.1007/978-94-017-2386-2_14.

Toro, G.R. (2002), Modification of the Toro et al. (1997) attenuation equations for large magnitudes and short distances, Tech. Rep., Risk Engineering, Boulder, Colorado, USA.

Wiejacz, P. (2006), The Kaliningrad earthquakes of September 21, 2004, Acta Geodyn. Geomater. 3, 2, 7-16.

Wiejacz, P., and W. Dębski (2009), Podhale, Poland, earthquake of November 30, 2004, Acta Geophys. 57, 2, 346-366, DOI: 10.2478/s11600-009-0007-8.

Wiejacz, P., and Ł. Rudziński (2010), Seismic event of January 22, 2010 near Bełchatów, Poland, Acta Geophys. 58, 6, 988-994, DOI: 10.2478/s11600010-0030-9.

Wiejacz, P., and J. Wiszniowski (2006), Moment magnitude determination of local seismic events recorded at selected Polish seismic stations, Acta Geophys. 54, 1, 15-32, DOI: 10.2478/s11600-006-0003-1.

Wilde-Piórko, M., W.H. Geissler, J. Plomerová, M. Grad, V. Babuška, E. Brückl, J. Cyziene, W. Czuba, R. England, E. Gaczyński, R. Gazdova, S. Gregersen, A. Guterch, W. Hanka, E. Hegedüs, B. Heuer, P. Jedlička, J. Lazauskiene, G.R. Keller, R. Kind, K. Klinge, P. Kolinsky, K. Komminaho, E. Kozlovskaya, F. Krüger, T. Larsen, M. Majdański, J. Málek, G. Motuza, O. Novotný, R. Pietrasiak, T. Plenefisch, B. Růžek, S. Sliaupa, P. Środa, M. Świeczak, T. Tiira, P. Voss, and P. Wiejacz (2008), PASSEQ 2006- 
2008: Passive seismic experiment in Trans-European Suture Zone, Stud. Geophys. Geod. 52, 3, 439-448, DOI: 10.1007/s11200-008-0030-2.

Wiszniowski, J. (2000), Application of real time recurrent neural network for seismic event detection, Acta Geophys. Pol. 48, 1, 1-26.

Wiszniowski, J., B.M. Plesiewicz, and J. Trojanowski (2014), Application of real time recurrent neural network for detection of small natural earthquakes in Poland, Acta Geophys. 62, 3, 469-485, DOI: 10.2478/s11600-013-0140-2.

Zuberek, W.M., and K. Jochymczyk (eds.) (2010), Origin and Seismic Hazard Assessment in the Upper Silesian Coal Basin, Wyd. Uniwersytetu Śląskiego, Katowice, 95 pp. (in Polish).

Received 16 September 2013

Received in revised form 16 June 2014

Accepted 18 June 2014 